\title{
Influence of liquid organic fertilizer on growth and yield of maize (Zea mays L.)
}

\author{
S. Sutharsan ${ }^{1}$ and M. Rajendran ${ }^{2}$ \\ 'Department of Crop Science, Faculty of Agriculture, Eastern University, Sri Lanka \\ ${ }^{2}$ Department of Agricultural Engineering, Faculty of Agriculture, Eastern University, Sri Lanka
}

\begin{abstract}
Since identification of sustainable and cost effective organic input is vital, an experiment was carried out at Crop Farm, Eastern University Sri Lanka, Vantharumoolai from May to August 2010 to investigate the effect of liquid organic mixture (Jeewamirta) on growth and yield of maize (cv. Pacific 984). The experimental design was randomized complete block design (RCBD) with four replicates. Different application frequencies of Jeewamirta were considered as treatments and treatments were defined as follows: T1-once a week application, T2-once in two weeks application, T3-once in three weeks application and T4- as control plot. Measurements viz. leaf area and plant biomass were taken at two weeks interval and data were analyzed statistically. The results revealed that there were significant $(p \leqslant 0.05)$ differences in leaf area and plant biomass. Highest leaf area and biomass were produced by plants belong to $T 1$, during reproductive and maturity stages. Significant differences $(p<0.05)$ were found in the grain yield and its components. Highest yield was obtained in T1, followed by $T 2$ and lowest grain yield was obtained from control treatment. The results indicated that application of Jeewamirta once a week could be a viable technique to increase maize production.
\end{abstract}

Keywords: Cow dung, fertilizer, maize

\section{Introduction}

Maize (Zea mays L.) is the top most ranking cereal in terms of higher grain yield and used as food and feed. Number of factors is responsible for low yield of which inappropriate crop nutrition management and poor soil fertility are the most important factors. Maize has been cultivated by the traditional farmers with increased application of synthetic fertilizers especially nitrogen as it shows higher response to applied nitrogen. The increased applications of fertilizers lead to more succulent crops which are vulnerable for various species of insects and diseases attacks (Palekar, 2005). The increased and often indiscriminate use of such fertilizers immensely harmed biological activity of the soil and rendering it almost lifeless in vast areas. In addition, inorganic cultivation causes soil erosion over 15 tones / ha of top soil lost on average and the left is coarser with less organic matter (Arun and Sharma, 2000).

Low use efficiencies of inorganic fertilizers coupled with their rising costs has directed the attention of farmers to wards organic sources. Organic manures may increase soil fertility and thus crop production potential possibly by changing physical and chemical properties of soil including nutrient bioavailability, soil structure, water holding capacity, cation exchange capacity, soil $\mathrm{pH}$, microbial community and its activity etc. (Marschner, 1995; Muhammad and Khattak, 2009). On the other hand, large amount of organic residues so required cannot be produced on small scale farms. Much attention has been paid in recent years to manage different organic waste resources in order to minimize cost of production and to cultivate crops eco-friendly (Suthar, 2007).

Microbial inoculants containing many kinds of naturally occurring beneficial microbes called 'Effective Microorganisms' has been used widely in nature and organic farming (Iwaishi, 2005). The utilization of non-traditional organic resources whose value has not been fully identified may offer alternative sources of organic manure. One such organic resource is Jeewamirta which has been used by farmers in Indian. Jeewamirta promotes 
immense biological activities in the soil and makes the nutrient available to the crops (Palekar, 2005). However, the use of Jeewamirta as an organic source for cultivation has been poorly investigated. Hence, in this study maize was used as an indicator crop to investigate the effects of Jeewamirta on growth and yield of maize (Zea mays L.).

\section{Materials and Methods}

This experiment was conducted at Crop Farm, Eastern University, Sri Lanka, Vantharumoolai from May to August 2010 to find out the inlluence of Jeewamirta on growth and yield of maize. The soil type was sandy regosol. The experiment was laid out in Randomized Complete Block Design (RCBD) with four replicates. Rotted cow dung at the rate of $10 \mathrm{t} /$ ha was applied as basal and thereafter Jeewamirta was applied as source of plant nutrients. Different application frequencies of Jeewamirta were considered as treatments and treatments were defined as follows: Tl-once a week application, T2-once in two weeks application, T3- once in three weeks application and T4- as control plot. Liquid organic mixture (Jeewamirta) was prepared in a $200 \mathrm{~L}$ plastic barrel with the ingredients at the rate of $10 \mathrm{~kg}$ of cow dung and $10 \mathrm{~L}$ of urine from indigenous cow, $2 \mathrm{~kg}$ of Jaggery, $2 \mathrm{~kg}$ of pulse powder and a handful of farm soil per acre. The all six ingredients were mixed in plastic barrel and stirred well. Then the barrel was covered with gunny mal. The barrel was placed in shade and stirred in clockwise twice a day in order to accelerate microbial activities. The prepared Jeewamirta was applied after three days of fermentation. Jeewamirta was diluted 10 times wilh water before application. All the agronomical practices except those under study kept normal and uniform for all the treatments. Parameters such as leaf area and plant biomass were taken at $4,6,8,10,12$ weeks after sowing (W $\wedge$ S). $\Lambda$ I 15 WAS, harvested cobs were air dried and parameters such as number of grains per row, number of seeds per cob, 100 seed weight and final grain yield $(\mathrm{Mt})$ per ha were measured. The data gathered in each observation were statistically analyzed using SAS 9.1 version statistical software package and mean comparison was performed within treatments using DMRT test at $5 \%$ significant level.

\section{Results and Discussion}

\section{Leaf Area}

There were significant differences in leaf area between treatments (Table 1). At $4^{\text {th }}$ WAS maximum leaf area of $3227.3 \mathrm{~cm}^{2}$ was recorded at T3, followed by T2 (3137.3 $\left.\mathrm{cm}^{2}\right)$ and TI $(3123.3$ $\mathrm{cm}^{2}$ ). The minimum leaf area of $626.8 \mathrm{~cm}^{2}$ was recorded in control treatment. Availability of nitrogen decreased in soil just after application of Jeewamirta due to immobilization and then increased with time.

\section{Table 1. Leaf area as influenced by dilferent nutrient management}

\begin{tabular}{|c|c|c|c|c|c|}
\hline Treatment & At 4th week & Al ollh week & At 81 h week & At 10 th week & Al 12 th week \\
\hline $\mathrm{Tl}$ & $3123.3 \pm 2.8^{\prime \prime}$ & $4019.5 \pm 3.5^{\prime \prime}$ & $5445.0 \pm 11.3^{31}$ & $6341.0 \pm 4.3^{\prime \prime}$ & $5529.5 \pm 10.6$ \\
\hline $\mathrm{T} 2$ & $3137.3 \pm 2.0^{\prime \prime}$ & $3969.0 \pm 1.3^{11}$ & $5051.5 \pm 7.3^{\prime \prime}$ & $5149.0 \pm 7.3^{b}$ & $3986.3 \pm 15.6^{10}$ \\
\hline $\mathrm{T} 3$ & $3227.3 \pm 2.5^{\prime \prime}$ & $3958.3 \pm 1.7$ & $5052.3 \pm 5.6^{\prime \prime}$ & $4801.8 \pm 12.9$ & $3975.3 \pm 14.2^{\prime \prime}$ \\
\hline T4 . & $626.8 \pm 0.9^{b}$ & $1723.8 \pm 1.7^{15}$ & $1527.8 \pm 2.1^{1}$ & $920.5 \pm 3.9^{\prime \prime}$ & $877.5+4.0^{c}$ \\
\hline$F$ - test & . & $*$ & $*$ & * & $*$ \\
\hline
\end{tabular}

Value represents mean \pm standard error of four replicales. "Signilicant at 5\% level of probability. Mean values in a column having the dissimilar leller/letlers indicate signilicint dillerences at $5 \%$ level of significance (I)MRT).

Maximum and minimum leaf area was obtained in $\mathrm{T} 1$ and $\mathrm{T} 4$ respectively in weekly measurements except $4^{\text {th }}$ WAS. As reported by Marambe et al. (1998) lower leaf area in control plot than plot amended with organic source. Marschner (1995) stated that $\mathrm{N}$ is essential for cell division, elongation as well as for root growth and dry matter content in maize plant. Low level of available nutrient produces crops with smaller leaf area limits carbon supply to the roots (Root uptake capacity) and formation of new shoots (Sink capacity). In maize cultivation $\mathrm{N}$ plays a major role in plant growth and development. Akandy (2006) stated that phosphorus content in soil was increased with application of cow dung. Improved plant height and leaf area in plants by organic manure application has been reported (Boateng el al., 2006; Muhammiad and Khattak, 2009). 
The leal area of the crop at a particular growth stage indicates its photosynthetic potential or the level of its dry matter accumulation. Rasheed et al. (2004) stated that higher leal areal attributed to higher dry matter accumulation potential of crop. It clearly indicates that application of Jeewamirta favours the maize plant growth.

\section{Plant biomass}

There were significant differences in leaf area between treatments (Table 2). Maximum and minimum plant biomass was recorded in $\mathrm{Tl}$ and T4 respectively except $4^{\text {th }}$ WAS. Maximum dry weight of $56.9 \mathrm{~g}$ was recorded in $\mathrm{T} 2$, followed by $\mathrm{T} /(34.9 \mathrm{~g})$ and $\mathrm{T} 3(28.7 \mathrm{~g})$. The minimum dry weight of $10.6 \mathrm{~g}$ was recorded in control plot at $4^{\text {th }}$ WAS.

Table 2. Plant biomass as influenced by different nutrient management

\begin{tabular}{|c|c|c|c|c|c|}
\hline Treatment & Al, 4 th week & Al 6lh week & Al 8th week & Al loth weck & si 12th week \\
\hline $\mathrm{Tl}$ & $34.9 \pm 2.8^{10}$ & $100.1 \pm 3.5^{\circ 1}$ & $227.4 \pm 11.3^{i \prime}$ & $276.6 \pm 4.3^{\prime \prime}$ & $327.7 \pm 10.6^{a 1}$ \\
\hline $\mathrm{T} 2$ & $56.9 \pm 2.0$ & $99.5 \pm 1.3^{\prime \prime}$ & $190.2 \pm 7.3^{10}$ & $248.6 \pm 7.3^{1}$ & $263.0 \pm 15.6^{\text {int }}$ \\
\hline T3 & $28.7 \pm 2.5^{11}$ & $102.4 \pm 1.7^{\mathrm{a}}$ & $208.9 \pm 5.6^{\prime \prime}$ & $203.5 \pm 12.9^{\circ}$ & $215.0 \pm 14.2^{c}$ \\
\hline $\mathrm{T} 4$ & $10.6 \pm 0.9^{\circ}$ & $38.9 \pm 1.7^{\mathrm{b}}$ & $45.0 \pm 2.1^{c}$ & $47.6 \pm 3.9^{\prime \prime}$ & $58.7 \pm 4.0^{\prime}$ \\
\hline F- test & $*$ & $*$ & $*$ & $*$ & * \\
\hline
\end{tabular}

Value represents mean \pm slandard cror of lour replicates. "Signilicant at $5 \%$ fevel of probabibly. Mean values in a column having the dissimilar letler/letlers indicale signilicant dillerences all 5\% level ol sighi!icance (l)Mkl').

At initial stage plant requires low nutricnts but adequate amount of nutrient is important for their growth and development. For the production of dry matter, nitrogen is an essential mutrient in addition to phosphorous and potassium. Planl biomass associated will dry matter production of plants and it depends on leaf area. lealf area index is the major determinant factor of photosynthesis and dry malter accumulation (Dwyer and Steward, 1986). The higher leal" area attributed to higher dry matter production in 'Tl than other treatments at later stage. The similar results also were reported by Marambe el al. (1998) who stated that unamended control plot produced lowest dry matter than plot treated with EM and other organic source. Srikrishmal ef al. (2010) stated that microbial activities increased availability of soil mutrients and thereby increased the leal area and biontass production ol crops. Raja e'f al. (2007) reported that when effective microorganisms increase as a community in soils, populations of native elfeclive microorganisms are also increased. Thus, the micro flora become rich and the microbial ecosystem in the soil become wellbalanced.

Soldati et al. (1.984) reported that an increase in dry matter accumulation leads to an increase in leaf area because proportion of dry matter allocated to leaves remain fairly constant while an increase in leaf area leads fo an increase in rate ol dry matter accumulation because light intereption is directly related to leal area during this phise of development. Rasheed et al. (2004) stated that crop growth ratc significantly higher in fertilized maize than unfertiaged maze. The rate of dry matter production begins to decline in treatments T2, '13 and 'T'4 due to lack of available nutrients in soil and due to low application of Jewamirta lhan '1. The similar trend was obtained by Rasheed 't al.(2004) who stated that plant biomass decline with time due to nutrient deficiency and plant senescence. Valero el al. (2005) reported higher values for net assimilation rate (NAR) during early vegetative growth but a decline during the latler stages, a situation which the authors attributed to a general decline in photosynthetic efliciency due to leal age and lack of nutrients in later stages.

\section{Yield and yield components Number of grains per row}

Data recorded on average number of grains per ear row is represented in table 3 . The response of grain number per row (per cob row) to different treatments was significant $(p<0.05)$. Maximum number of grains per row (3.3.7) was recorded when Jeewamirta applied onee a week interval while minimum grain number (17.3) was observed in control trealment. The reason behind that may be the diflerence in available nutrient to the erops 
among different treatments. Similar results were observed by Marambe et al. (1998) who reported that when increasing the concentration of EM enhanced the grain number and grain weight per cob.

\section{Number of grains per cob}

Maximum number of grain per cob (483) was recorded in plot which received Jeewamirta once a week while minimum "number (170) was recorded in control treatment. These results might be due to the variation in nutrient availability among the treatments. This was supported by Rasheed et al. (2004) who stated that seed number increases with increased available $\mathrm{N}$ and $\mathrm{P}$. The $P$ level increased with increased level of cow dung applied (Akandy et al., 2006).

The present results indicated the vital role of Jeewamirta liquid fertilizer in increasing the availability of $\mathrm{N}$ and $\mathrm{P}$ in soil. Hussaini et al. (2002) stated that substantial increase in grain yield primarily arising from $\mathrm{N}$ availability and secondarily from P. Application of jeewamirta improved nutrient availability through enhanced microbial activities. Increased microbial activity in rhizosphere and released organic substances by plants might be responsible for higher organic matter contents in the rhizosphere soil than in bulk soil (Marschner, 1995).

Due to the higher microbial activity in T1 compared with other treatments, it produces organic acids and thus increases the availability of native $\mathrm{P}$ and other nutrients through decomposition process (Palekar, 2005). Carbonic acid produced after the decomposition increased P bioavailability (Marschner, 1995). It has been reported that humic acids increase the number of roots thereby increase the growth and plant development of maize (Alvarez and Grigera, 2005).

\section{Average weight of 100 seeds}

Application of Jeewamirta had significant different $(p<0.05)$ in 100 seed weight. The maximum weight of $20.9 \mathrm{~g}$ was observed in $\mathrm{T} 1 \mathrm{but}$ statistically was equivalent to T2 $(20.7 \mathrm{~g})$ and T3 $(20.0 \mathrm{~g})$ while significantly minimum weight $(18.2 \mathrm{~g})$ was recorded in control plot. It may be due to the difference in application frequency of Jeewamirta liquid fertilizer. Poor dry matter partitioning to the grains, lower leaf area may be the reasons for lowest 100 seeds weight in control treatment. Sangakkara et al. (1993) reported that increasing the availability of nutrients increases the number of grains and grain weight of maize. The most critical phase for $\mathrm{N}$ supply is the grain filling stage when the canopy $\mathrm{N}$ levels typically decline as the plant progresses to maturity (Christensen et al., 1981) and retranslocation of $\mathrm{N}$ from leaves and the stem to ears predominate (Lemaire and plenet, 1999). Higher availability of nutrient in grain filling stage attributed to higher value in 100 seeds weight in T1 than other treatments.

\section{Grain yield}

The grain yield was significantly affected by the treatments' effect. The grain yield varied between $1.9 \mathrm{t} /$ ha in control and $6.1 \mathrm{t} / \mathrm{ha}$ in treatment which received Jeewamirta once a week (Table 3 ). The reasons may be the difference in nutrient availability among the treatments. Yield differences among the treatments of $\mathrm{T} 1, \mathrm{~T} 2$ and T3 might be due to different level of N. Similar trends in yield differences across $\mathrm{N}$ levels have been reported by Sharifi et al. (2009). Sanjeev and Bangarwa (1997) reported that grain yield increased with increasing $\mathrm{N}$ level. The highest yield obtained in $\mathrm{T} 1$ might be due to its superiority in yield components. Liquid formula of Jeewamirta consisting of huge number of beneficial microbes and thus improves the soil fertility level through natural process. Cyanobacteria as promissory microorganisms improve the decomposition of death planting materials and increasing the activity of the soil micro flora. It further improved the recycling of essential nutrients with further advantage of ensuring sustainability of ecosystem, because there is a continuous renewable carbon source and also contributing in fixing $\mathrm{N}$ and $\mathrm{P}$ mobilization (Zulpa et al., 2008).

When increased the application of Jeewamirta, it increases the amount of availability of nitrogen and possibly other essential nutrients and thus increase the dry weight and yield of maize. Addition of 
nitrogen increases small roots and root hairs which in turn facilitated the high absorbing capacity per unit of dry weight (Hussaini et al., 2008). Ojeniyi et al. (2010) stated that increased availability of nutrients in soil and maize crop led to enhanced growth and cob yield.

Table 3. Yield and yield components as influenced by different nutrient management

\begin{tabular}{ccccc}
\hline Treatment & $\begin{array}{c}\text { No. of grains } \\
\text { per row }\end{array}$ & $\begin{array}{c}\text { No. of grains } \\
\text { per cob }\end{array}$ & $\begin{array}{c}100 \text { seed weight } \\
(\mathrm{g})\end{array}$ & $\begin{array}{c}\text { Grain yield } \\
(\mathrm{t} / \mathrm{ha})\end{array}$ \\
\hline $\mathrm{T} 1$ & $33.7 \pm 0.9^{\mathrm{a}}$ & $483.0 \pm 22.5^{\mathrm{a}}$ & $20.9 \pm 0.3^{\mathrm{a}}$ & $6.1^{\mathrm{a}}$ \\
$\mathrm{T} 2$ & $28.3 \pm 0.9^{\mathrm{b}}$ & $377.7 \pm 13.4^{\mathrm{b}}$ & $20.7 \pm 0.3^{\mathrm{a}}$ & $4.7^{\mathrm{b}}$ \\
$\mathrm{T} 3$ & $24.3 \pm 0.7^{\mathrm{b}}$ & $307.3 \pm 7.3^{\mathrm{c}}$ & $20.0 \pm 0.1^{\mathrm{a}}$ & $3.7^{\mathrm{c}}$ \\
$\mathrm{T} 4$ & $17.3+2.3^{\mathrm{c}}$ & $170.0 \pm 33.2^{\mathrm{d}}$ & $18.2 \pm 0.2^{\mathrm{b}}$ & $1.9^{\mathrm{d}}$ \\
\hline F- test & $*$ & $*$ & $*$ & $*$ \\
\hline
\end{tabular}

Value represents mean \pm standard error of tour replicates. ${ }^{*}=$ Significant at $5 \%$ level of probability. Meajialues in a column having the dissimilar letter/letters indicate significant differences at $5 \%$ level of significance (DMRT).

\section{Conclusions}

From these results it could be concluded that application of Jeewamirta liquid organic fertilizer had significant effect on maize growth and yield. Based on the findings, application of Jeewamirta once a week with incorporation of organic manure as basal can be the alternative organic source of nutrient to obtain optimum yield in sustainable and environmental friendly manner.

\section{References}

Akandy, M.O., F.I. Oluwatoyinbo., C.O. Kayode and F.A. Olowokere (2006). Response of Maize (Zea mays) and Okra (Abelmo schusesculentus) Intercrop Relayed with Cowpea (Vigna unquiculata) to Diffe rent Cow dung Amended Phosphate Rock. World Journal of Agriculture Science 2 (1): 119-122.

Alvarez and S. Grigera (2005). Analysis of soil - fertility and management effects on yields of wheat and corn in the rooling pampa of Argentina. Journal of Agronomy and Crop Science 191 (5): 321-329.

Arun. K. S. (2000). A Hand book of Organic Farming. Agrobios (India), Johdhpur. p. 628.

Boateng, S.A., J. Zichermann and M. Kornahrens (2006). Poultry manure effect on growth and yield of maize. West Africa Journal of Applied Ecology 9: 1-11.
Christensen, L.E., F.E. Below and R.H. Hageman (1981). The effects of ear removal on $s$ enescence and metabolism of maize. Journal of Plant Physiology 68:1180-1 185.

Dwyer, L. M. and D.W. Stewart (1986). Leaf area development in field-grown maize. Agronomy Journal 78: 334-343.

Hussaini, M.A., V.B. Ogunlela., A.A. Ramalan., A.M. Falaki and A.B. Lawal (2002). Productivity and Water use in Maize (Zea mays L.) as Influenced by Nitrogen, Phospliorus and Irrigation Levels. Crop Research 23: 228-234.

Hušsaini, M.A., V.B. Ogunlela and A.A. Ramalan (2008). Mineral Composition of Dry Season Maize (Zea mays) in Response to Varying Levels of Nitrogen, Phosp horus and irrigation at Kadawa, Nigeria. World Joumal of Agricultural Scie nces 4 (6): 775-780.

Iwaishi. (2005). Effect of organic fertilizer and effective microorganisms on growth, yield and quality of vineyards. The journal of General and applied Microbiology 51(5): 313-318.

Lemaire, G. and D. Plenet (1999). Relationships between dynamics of nitrogen uptake and dry matter accumulation in maize crops. Determination of critical $\mathrm{N}$ concentration. Journal of Plant and Soil 216: 65-82. 
Marambe, B., .U.R. Sangakkara and Y.D.A. Senanayake (1998). limpact of elfective microorganisms on dry matter partitioning in maize (Zea mays L.). In Fifth Intern ational Conference on Kyusei Nature Farming, (Y.D.A. Senanayake and U.R. Sangakkara, eds.), p. 112-119. APAN; Bangkok, Thailand.

Marscliner, H. (1995). Mineral Nutrition of Iligher Plants. Academic Press International, San Diego, CA, USA.

Mulammad, D. and R.A. Khattak (2009). Growlh and nutrient concentration of maize in pressmud treated saline - sodic soils. Journal of Soil and Enviromment 28: 145-155.

Ojeniyi, S. O., B.L. Awanlemlen and S.A. Adejoro (2010). Soil Plant Nutrients and Maize Performance as Influenced by Oilpalm Bunch Ash plus NPK Fertilizer. Journal of American Science 6 (12): 456-460.

Palekar, S. (2005). Aanma velanmayin thathvam, Amith subash palekar, Zero budget iyatgaivelanmai, aarachchi, valarchchi virivakka iyakkam. Lanc number-5, Namuna peddai, Amaravathi - 444607. Maharastra, Indii, p. 144-191.

Raja,K:N. and Kirithiga. (2007). Ellect of form ulation ol effective microorganism (EM) on post treatment persistence, microbial density and soil macro mutrients. Recent Rescarch in Science and Technology 2(5): 102-106.

Rasheed, M., A. Hussain and T. Mahmud (2004). Growth analysis of Hybrid maize as Influenced by planting technicues and nutrient management. International.Jour nal of Agricullure and Biology 5(2) 169 . 171.

Sangakkara, U.R., K.B. Attanayake., A.D. A. Ratnayake and E.R. Piyadasa (1993). The role of microorganism in releasing nutri ents from organic matter. In Proceeding of Third International comgress. Pn EM Technology of APNAN. Saraburi Thailand.pp.6-15
Sanjeev, K. and A.S. Bangarwa (1997). Yield and yield components of winter mize ( $Z$ ea mays L.) as plant density and nitrogen levels. Agricultural Science Digest (Karnal) 17:181-184.

Sharifi, R. and R. Taghizadeh (2009). Response of maize (Zea mays) cultivars to different levels of nitrogen lertilizer. Journal of Food. Agriculture and Emiromment 7 (3 and 4): 518-521.

Soldati, A., A. Stchli and P'. Stamp (1984). Temperature adaptation of tropical high land Maize (Zeal mongs L.) during early growh and in controlled conditions. . Journal of ('rop) Sicience 24:28-32.

Srikrishnah, S., S. Sutharsinn and M. Rajendran (2010). Selected organic fertilization on Growth and yicld of cowpea (cv Wartmi) in sandy regosol of Batticaloa district. $9^{\text {th }}$ Anmual Research Sessiom, Eastern, University, Sri lamka. p.44.

Suthar, S. (2007). Vermicomposting potential Perionyx sansibaricus (Perrier) in diffe rent waste materials. Bioresonere Tech mology 98 (6): 1231-1237.

Valero, ^., M.M. de Juam., ^.^. Ramurez., J.M. Tarjuelo Martun-Benito and J.F. Orlegal bilvare (2005). Growtl and nitrogen use efliciency of irrigaled maize in a semiarid region as allected by nitrogen fertilization. Spamish Jomrnal of Agricultural Res earch 3(1): 134-144.

Zulpa, G., li.S. Maria., C.Z. Maria., S. Monica and P. Martha (2008). Eiffect of (yamo bercteria on the Soil Microllora Activi ty and Maize Remains Degradation in a Culture Chamber Experiment. Imernati onal . Inurnal of Agriculture and Bio $\log y$ 10: 388-392. 